\title{
Las Animas Formation (Upper Precambrian) in the Subsurface of Southeastern Colorado
}

GEOLOGICAL SURVEY BULLETIN 1529 -G

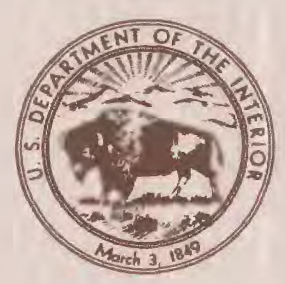





\section{Las Animas Formation}

(Upper Precambrian)

in the Subsurface of

Southeastern Colorado

By OGDEN TWETO

CONTRIBUTIONS TO STRATIGRAPHY

GE OLOG I C A L S U R VEY B U L L E T I N $1529-$ G

Definition and description of $a$ unit of moderately metamorphosed sedimentary and volcanic rocks

of late Precambrian age

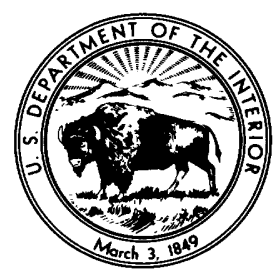




\title{
UNITED STATES DEPARTMENT OF THE INTERIOR
}

\author{
JAMES G. WATT, Secretary
}

GEOLOGICAL SURVEY

Dallas L. Peck, Director

Library of Congress Cataloging in Publication Data

Tweto, Ogden, 1912-

Las Animas formation (upper Precambrian) in the subsurface of southeastern Colorado.

(Contributions to stratigraphy) (Geological Survey Bulletin 1529-G)

Bibliography: 14 p.

Supt. of Docs. No.: I 19.3:

1. Geology, Stratigraphic-Precambrian. 2. Geology-Colorado.

I. Title. II. Series. III. Series: Geological Survey Bulletin 1529-G.

QE75.B9 no. 1529-G 557.3s [551.78'15] 82-600011

AACR2

[QE653]

For sale by the Branch of Distribution, U.S. Geological Survey, 604 South Pickett Street, Alexandria, VA 22304 


\section{CONTENTS}

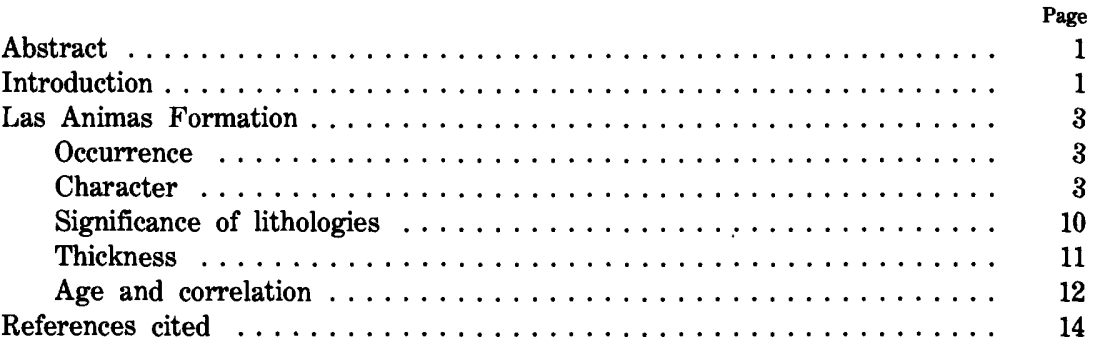

\section{ILLUSTRATIONS}

Figure 1. Index map of southeastern Colorado . . . . . . . . . 2

2. Subsurface geologic map of Precambrian basement in southeast

Colorado ...................... 4

3. Map showing relation of Las Animas Formation to Wichita province

\section{TABLE}

TABLE 1. Boreholes into Las Animas Formation, southeastern Colorado . 



\title{
CONTRIBUTIONS TO STRATIGRAPHY
}

\section{LAS ANIMAS FORMATION (UPPER PRECAMBRIAN) IN THE SUBSURFACE OF SOUTHEASTERN COLORADO}

\author{
By OGDEN TWETO
}

\begin{abstract}
A thick sequence of slightly to moderately metamorphosed rocks that lies beneath unmetamorphosed Upper Cambrian rocks in the subsurface of southeast Colorado is herein designated the Las Animas Formation. The formation occupies a belt about $130 \mathrm{~km}(80 \mathrm{mi})$ long and as much as $50 \mathrm{~km}(30 \mathrm{mi})$ wide as established from borehole data. The formation consists principally of dark-gray to black slate, phyllite, finegrained graywacke, and chert. Carbonate and volcanic rocks are present in addition in an upper part, much of which is dark red. Thickness of the formation is not known but exceeds a total of $1,700 \mathrm{~m}(5,575 \mathrm{ft})$ penetrated in two boreholes in different parts of the formation.

The Las Animas Formation lies on Precambrian granite of 1,300-1,400 m.y. age and is overlain by Upper Cambrian rocks. On the basis of its metamorphic character and position unconformably below Upper Cambrian rocks, it is classed as late Precambrian in age.

The Las Animas Formation closely resembles the Tillman Metasedimentary Group of Ham, Denison, and Merritt (1964) in the Wichita Mountains province of southern Oklahoma. The two units also share the same age brackets, and both are interpreted to have been deposited in deep west-northwest-trending troughs of rift origin. They probably represent responses in different areas to the same tectonic event.
\end{abstract}

\section{INTRODUCTION}

Somewhat metamorphosed rocks beneath unmetamorphosed Cambrian or younger Paleozoic rocks in the subsurface in southeastern Colorado first came to attention with the drilling in 1927-28 of the Phillips Petroleum Co. No. 1 E. W. Haskins well in sec. 23, T. 29 S., R. 56 W., Las Animas County. The presence of the older rocks in this well was noted by Heaton $(1933$, p. 136) who described the rocks as red slate of probable Precambrian age. In conjunction with regional subsurface studies, Maher and Collins (1949) described the rocks of the Haskins well a little more fully as predominantly shale or phyllite but consisting also of igneous rocks, arkosic sandstone, and limestone or marble. Later, Edwards (1966) made petrographic examinations of igneous rocks from among the samples in four other boreholes. On the basis of those samples, he designated this area of 
basement rocks as a Precambrian volcanic terrane (Edwards, 1966, pl. 1), and it is so shown on the basement map of the United States (Bayley and Muehlberger, 1968). However, the volcanic designation is misleading. The rocks of the area are predominantly sedimentary as shown by several other boreholes and by holes that penetrated deep into the sequence below the Upper Cambrian rocks.

The sequence of slightly to moderately metamorphosed sedimentary and igneous rocks that lies below Upper Cambrian or younger Paleozoic rocks in southeast Colorado is here designated the Las Animas Formation, a lithostratigraphic unit. The formation is named for Las Animas County (fig. 1), where it occupies an extensive area in the subsurface.

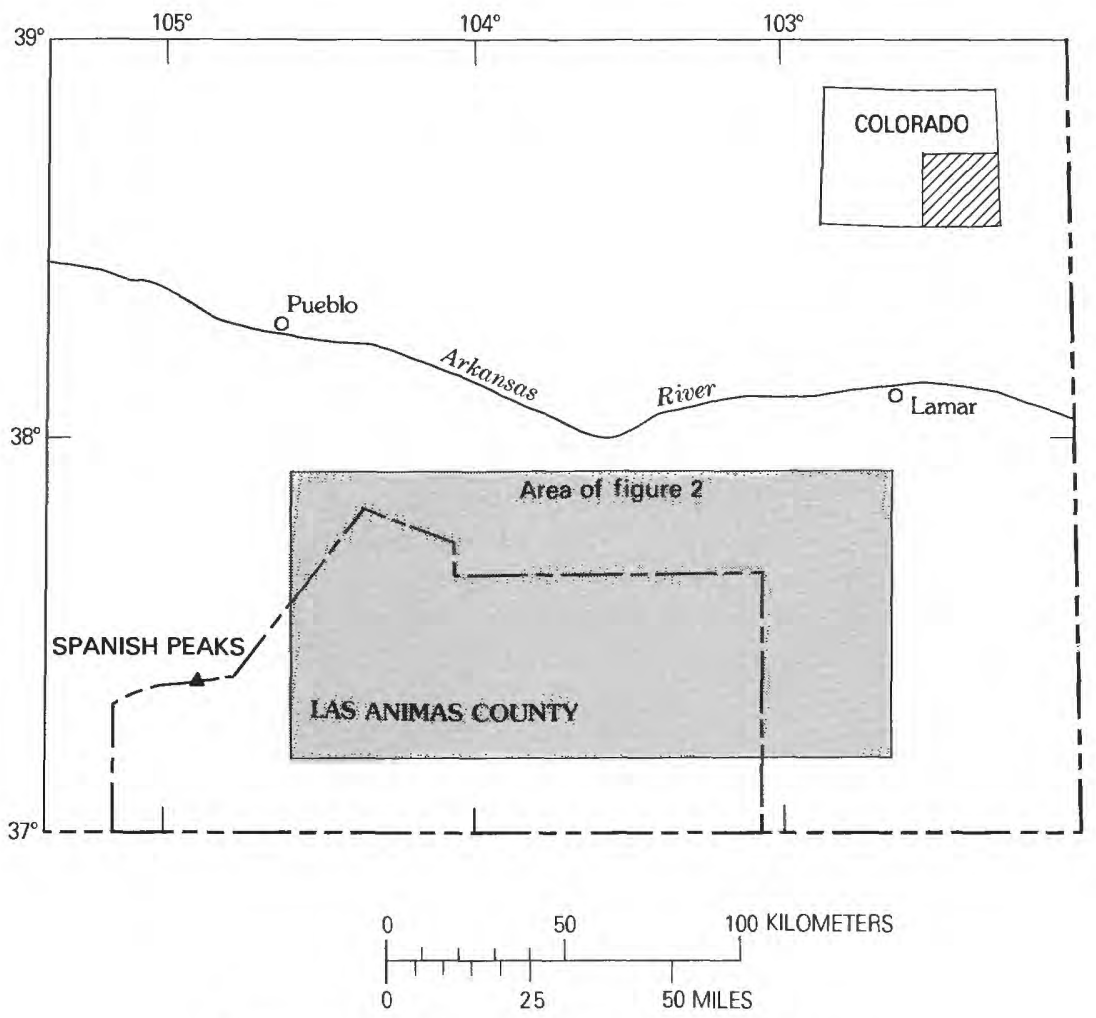

Figure 1.-Index map of southeastern Colorado. 


\section{LAS ANIMAS FORMATION}

\section{OCCURRENCE}

The Las Animas Formation constitutes part of a buried but structurally high tract of Precambrian basement rocks called the Apishapa highland, a Pennsylvanian uplift that is now covered by Permian and younger rocks. The formation consequently is not exposed anywhere at the surface, but it has been reached at comparatively shallow depths in several boreholes. Knowledge of the formation comes from 13 such boreholes scattered through T. 26-30 S., R. 50-63 W. (fig. 2). In those boreholes, the Las Animas was reached at depths of 340 $1,335 \mathrm{~m}(1,115-4,380 \mathrm{ft})$. Most of the holes penetrated less than 30 $\mathrm{m}(100 \mathrm{ft}$ ) into the formation (table 1), but the R. W. Lange No. 1 Government (sec. 10, T. 29 S., R. 62 W.) penetrated 1,270 m (4,165 $\mathrm{ft}$ ) and the Haskins well penetrated $431 \mathrm{~m}(1,415 \mathrm{ft})$.

As interpreted from the borehole data, the Las Animas Formation occupies an east-trending fault-bounded belt, or graben, at least 130 $\mathrm{km}(80 \mathrm{mi})$ long and as much as $50 \mathrm{~km}$ (30 mi) wide (fig. 2). Within this belt, the formation is overlain locally by Upper Cambrian rocks but in most places by younger Paleozoic rocks, principally the Permian. The base of the formation has not been reached by the drill, and, as the structure within the graben is unknown, the thickness is unknown beyond the fact that it must exceed that penetrated in the boreholes. As judged from the basement rocks bordering the graben, the Las Animas Formation rests principally upon granite of $\backsim 1,400$ m.y. age but in part upon much older felsic and hornblendic gneisses. Age of the formation, discussed at the end of the report, is thus broadly bracketed as being younger than about 1,400 m.y. and older than Late Cambrian.

\section{CHARACTER}

Information on the character of the Las Animas Formation comes principally from the Lange Government and Haskins wells, supplemented by data from several other wells (table 1). Samples from the Lange Government well have been logged in reconnaissance by me as tabulated in the type well that follows. They have also been logged by the American Stratigraphic Company ${ }^{1}$ (AmStrat Log D-1214), and three specimens from deep in the hole were examined petrographically 

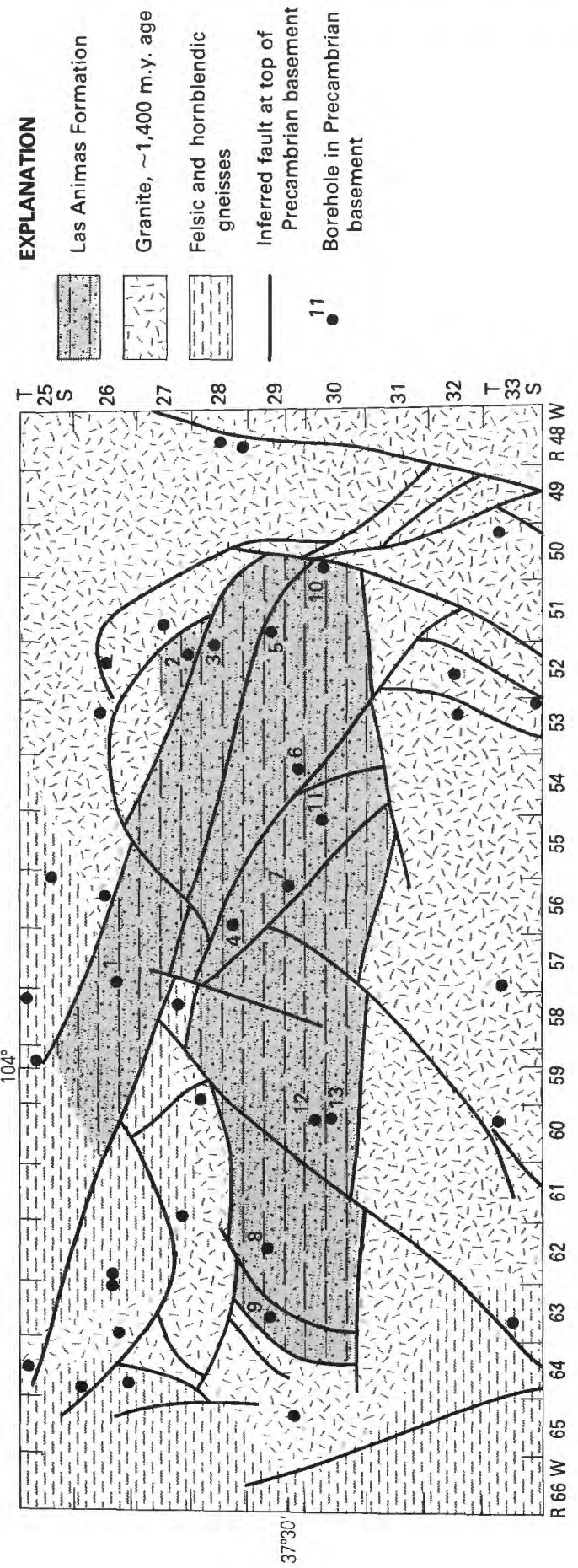

률

。ำ

氜.

运类

율

อี

ธี -

芑总

政

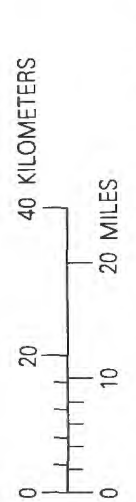

嶨

हี

马्.

范

ค สี -

유유

要 总

है छु

공

㟧

얼 틍

突

药 药

? 突.

ง

일

总 
by Edwards (1966, p. 254-256). Samples from the Haskins well were examined in the 1940's by J. C. Maher of the U.S. Geological Survey but were subsequently lost. Maher (unpublished well log) classed much of the rock as shale but noted that the shales "may be phyllites" and that they are "hard and somewhat granular." In a stratigraphic reference well that follows, Maher's log is interpreted in light of the observed character of rocks in the Lange Government well.

At the site of the Lange Government well, the Las Animas Formation consists almost entirely of dark-gray to black slate, phyllite, finegrained graywacke, and recrystallized chert. The slates and graywackes are markedly siliceous and both grade in places into chert. The slates also give way downward to phyllites, and the phyllites become coarser in grain with depth. In the lower part of the hole, the phyllites contain conspicuous biotite and grade to hornfelses that contain scattered metacrysts of a light-green amphibole, probably actinolite, and a dull green-gray pyroxene, probably diopside. Detrital grains of quartz and chert in the slates and phyllites are angular and range in size from well to poorly sorted. In most of the rocks the detrital grains are in a matrix that is more siliceous than ordinary argillaceous matter, but some of the rocks are well-sorted siltstones essentially devoid of matrix material. The graywackes are coarser in grain than the slates and phyllites but otherwise are texturally similar, consisting of angular or subangular grains of various sizes in a finegrained siliceous matrix. In the matrix of the rocks at depth, chlorite, sericite, biotite, and plagioclase are visible under low magnification. Clastic grains in the graywackes are quartz, chert, feldspars, and finegrained aggregates that probably represent altered rocks. In places the dark fine-grained graywackes contain thin beds of white to buff coarse-grained quartzite consisting of well-sorted subangular quartz grains. Some such quartzite contains minute clots or stringers of green silicate minerals and seems to have been limy. In the chert that is interbedded with the graywackes and pelites, original black chert is recrystallized and bleached in varying degree. A wide range in crystal size characterizes the cherts, and a progressive change in crystal size and color can be observed even in small chips. Aggregates of moderately coarse grained crystalline quartz in some graywacke layers probably represent thoroughly recrystallized chert.

The section of metamorphosed sedimentary rocks penetrated by the Lange Goverment well is designated the type well of the main part of the Las Animas Formation. The section ends an unknown distance above the base of the formation and thus is not an ideal type section, but it is the best available. The thicknesses listed are only apparent because structure and the attitude of bedding are unknown.

\footnotetext{
${ }^{1}$ Use of company names is for descriptive purposes only and does not constitute endorsement by the U.S. Geological Survey.
} 


\section{Type well of main part of Las Animas Formation}

[Interpreted from cuttings from the R. W. Lange No. 1 Government test well, SW $1 / 4 \mathrm{NW} 1 / 4$ sec. 10, T. $29 \mathrm{~S}$., R. 62 W., Las Animas County, Colo. Well drilled in 1958; surface elevation 5,659 ft. Section begins at unconformity below base of Permian rocks (Sangre de Cristo Formation) at depth 2,045 ft $(623.3 \mathrm{~m}$ ) in well, and ends in Las Animas Formation at total depth of 6,210 $\mathrm{ft}(1,893 \mathrm{~m})$. Well samples are in custody of the American Stratigraphic Company (AmStrat), Denver, Colo.]

Depth (feet)

Apparent thickness Meters

Feet

Las Animas Formation:

2,045-2,100 Quartzitic graywacke, red-brown, fine-grained; color is due to weathering ..............

$2,100-2,160$ Siliceous slate, dark-gray to black, and thin layers of gray micaceous phyllite ...........

$18.3 \quad 60$

$2,160-2,180$

Graywacke, dark-gray . . . . . . . . . . . .

6.120

$2,180-2,210$

Siliceous slate, black, and some hard mudstone and phyl-

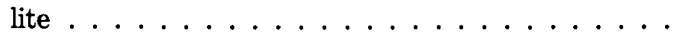

2,210-2,300 Graywacke, dark-gray and minor red-brown; contains dark chert grains . . . . . . . . . . . . . . .

$2,300-2,500$

$2,500-2,600$

$2,600-2,750$

$2,750-2,840$

$2,840-2,860$

$2,860-2,950$

$2,950-3,200$

$3,200-3,570$

Siliceous slate, dark-gray to black, and some graywacke. Slaty siltstone in cored interval is dark gray, finely laminated, composed of even-sized angular grains .

Phyllite, gray, gritty, and some siliceous slate . . . .

$30.5 \quad 100$

$\begin{array}{llll}\text { Siliceous slate, dark-gray, and intergrading phyllite } & 45.7 & 150\end{array}$

Quartzitic graywacke, black, fine-grained . . . . . . $27.4 \quad 90$

Siliceous slate, dark-gray to black . . . . . . . . . 6.120

Quartzitic graywacke, black, fine-grained ....... 27.490

Siliceous slate and subordinate phyllite, dark-gray to black . . . . . . . . . . . . . . .

$76.2 \quad 250$

Quartzitic graywacke, dark-gray, fine-grained; some is phyllitic or finely schistose; includes a few thin beds of light-gray coarse-grained quartzite with angular

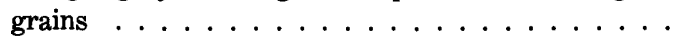

3,570-3,630 Interlaminated quartzitic graywacke and recrystallized chert ..................

3,630-3,710 Graywacke and abundant coarsely crystalline white quartz (from chert?) . . . . . . . . . . . .

3,710-3,820 Quartzitic graywacke, gray to dark-gray, and interlaminated dark-gray partly recrystallized chert . . . .

$3,820-3,890$ Recrystallized chert, light- to dark-gray, and interlaminated quartzitic graywacke; some white vein quartz .

3,890-3,970 Graywacke. Contains abundant coarse grains, mainly angular, of quartz, chert, and some feldspar in finely crystalline matrix that contains much biotite and (or) chlorite. Clots of fine-grained biotite probably represent rock grains ...............

3,970-4,150 Graywacke, recrystallized chert, and phyllite, dark-gray; and some buff to white coarse- and angular-grained quartzite. Some of quartzite pyritic, and some has nests of green chlorite. No evidence seen of quartz latite porphyry reported at $4010-4020 \mathrm{ft}$ by Edwards $(1966$, p. 254) . . . . . . . . . . . . . . dark-gray; possibly some fine-grained metavolcanic rock 
4,260-4,400 Recrystallized chert, graywacke, and white to pale-green uneven-grained quartzite ............

4,400-4,480 Quartzitic graywacke, dark- gray, and some interbedded light-gray to green quartzite and chloritic quartzite .

4,480-4,530 Quartzitic graywacke and recrystallized chert, dark-gray

4,530-4,550 Quartzite, light-gray, uneven-grained; angular to subrounded grains; some quartzitic graywacke ... .

4,550-4,590 Graywacke and subordinate quartzite, gray . . . . .

$4,590-4,640$ Siliceous slate, grading to gritty phyllite; dark gray .

15.250

$4,640-4,680$

Quartzitic graywacke and recrystallized chert, dark-gray

4,680-4,710 Recrystallized chert, light- to dark-gray . . . . . . .

$4,710-4,800$ Quartzitic graywacke and subordinate recrystallized chert, gray to dark-gray . . . . . . . . . . .

4,800-4,880 Siliceous mudstone, gray; and some green-gray sericitic quartzite . . . . . . . . . . . . . .

4,880-4,930 Graywacke and fine-grained biotitic phyllite . . . . .

4,930-5,150 Siliceous mudstone, dark-gray; grains are mainly quartz; fine-grained biotite and chlorite in matrix .....

$5,150-5,320 \quad$ No samples . . . . . . . . . . . . .

$5,320-5,450$ Siliceous quartz-biotite mudstone, gray; some finely schistose . . . . . . . . . . . . . .

$5,450-5,540$ Siliceous mudstone as above but hornfelsic with porphyroblastic mafic crystals, probably pyroxene . .

5,540-5,650 Quartzitic graywacke and mudstone, dark-gray; contains porphyroblastic mafic crystals and thin gray-green limy streaks containing calc-silicate minerals ...

$5,650-5,860$ Quartz-biotite hornfelsic phyllite and fine-grained schist; gray and dark gray; contains a few large actinolite

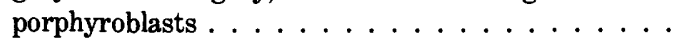

9.130

$27.4 \quad 90$

$24.4 \quad 80$

$15.2 \quad 50$

$67.1 \quad 220$

$51.8 \quad 170$

$39.6 \quad 130$

$27.4 \quad 90$

$33.5 \quad 110$

$64.0 \quad 210$

$5,860-5,870$ Biotite-chlorite hornfelsic phyllite . . . . . . . .

$3.0 \quad 10$

$5,870-5,885$ Pegmatitic pink quartz . . . . . . . . . .

5,885-6,090 Biotite-chlorite hornfelsic phyllite; dark green gray; some

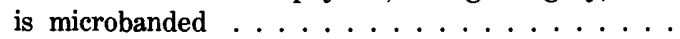

6,090-6,150 Phyllite or hornfels, gray, microbanded, and pink vein quartz ................. $18.3 \quad 60$

$6,150-6,210$

Phyllite or hornfels, gray; some is microplicated . .

$18.3 \quad 60$

Total depth, Total apparent thickness drilled, main part of Las

6,210

Animas Formation . . . . . . . . . 1,269.3 4,165

At the site of the Haskins well, $60 \mathrm{~km}(37 \mathrm{mi})$ east of the Lange Government well, the Las Animas Formation also consists principally of slate, phyllite, and fine-grained graywacke, but it differs in some respects: It contains layers of volcanic and intrusive rocks; it is dark red or maroon in its upper part; and it contains several thin carbonate beds as well as thin beds of conglomerate and arkose. The following section, freely interpreted from entries in Maher's log of the Haskins well, is designated a reference well for the upper part of the Las Animas Formation. Like the Lange Government section, this section is incomplete, the top being an unconformity and the base not having 
been reached, but more satisfactory sections are hardly to be expected in the future. The Lange Government and Haskins wells proved the presence and considerable thickness of the Las Animas Formation, and there is no further reason to drill deeply into it in petroleum exploration.

\section{Reference well of the upper part of the Las Animas Formation}

[Interpreted from lithic $\log$ of the Phillips Petroleum Co. No. 1 E. W. Haskins well, NE $1 / 4 N^{1 / 1 / 4}$ sec. 23, T. 29 S., R. 56 W., Las Animas County, Colo. Well drilled in 1927-28; surface elevation 4,648 ft. Original log by J. C. Maher, about 1945 (unpub. well log, U.S. Geological Survey files). Section begins at unconformity beneath base of Upper Cambrian sandstone (Reagan Sandstone) at depth of $340 \mathrm{~m}(1,115 \mathrm{ft}$ ) in well and ends in the Las Animas Formation at depth of $771 \mathrm{~m}(2,530 \mathrm{ft})]$

Las Animas Formation:

Meters

Feet

$1,115-1,200$

Porphyritic andesite, brown ...........

25.9

$1,200-1,280$

Slaty rock, dark maroon

24.4

$1,280-1,332$

Phyllite and fine-grained graywacke, dark maroon . .

$1,332-1,336$

Conglomerate; milky chert clasts in feldspathic sandstone

15.9

1.2

80

$1,336-1,372$

Phyllite, maroon, and scattered thin beds of pink to red finely granular dolomite . . . . . . . . . .

$1,372-1,378$

$1,378-1,385$

$1,385-1,397$

$1,397-1,400$

$1,400-1,406$

$1,406-1,422$

$1,422-1,475$

$1,475-1,575$

$1,575-1,597$

$1,597-1,648$

$1,648-1,650$

$1,650-1,665$

$1,665-1,678$

$1,678-1,685$

$1,685-1,710$

$1,710-1,715$

$1,715-1,740$

$1,740-1,788$

$1,788-1,830$

$1,830-1,890$

$1,890-1,970$

$1,970-1,975$

$1,975-2,005$

$2,005-2,135$

$2,135-2,140$
Dioritic igneous rock, maroon; weathered sill? . . . .

Phyllite, maroon ...............

Basalt or dark andesite ...............

Conglomerate; chert clasts in white feldspathic sandstone

Sericite schist, green-gray . . . . . . . . . . .

Graywacke, fine-grained, in alternating maroon and green-gray layers ..............

Phyllite, maroon ..............

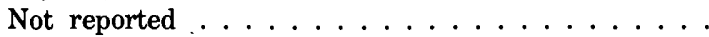

Arkosic limestone, maroon . . . . . . . . . . . .

Graywacke, maroon; contains dark-green chloritic frag-

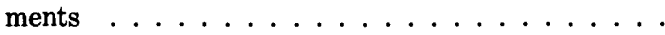

Limestone, white to pink, finely crystalline . . . . . .

Phyllite, maroon; some contains limestone fragments . .

Gritty phyllite, maroon; contains dark-green chloritic

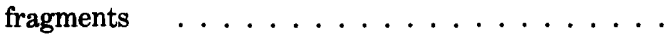

Andesite, maroon . . . . . . . . . . .

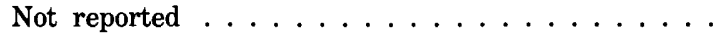

Arkose . . . . . . . . . . . . . . . .

Chlorite schist, dark-gray to black . . . . . . . .

Graywacke, maroon, and thin interbeds of gray sericite schist . . . . . . . . . . . . . .

Phyllite, maroon, and minor gray schist . . . . . .

Phyllitic graywacke, gray-maroon, and thin interbeds of gray sericite schist . . . . . . . . . .

Phyllite, maroon, and a few thin beds gray schist. . Dolomite, pink, dense to finely granular ...... Gritty phyllite, banded gray and maroon ....... Phyllite, dark-gray to black . . . . . . . . . . . Limestone, gray, finely crystalline . . . . . . . .
$11.0 \quad 36$

1.86

2.17

$3.7 \quad 12$

$0.9 \quad 3$

1.86

$4.9 \quad 16$

16.153

$30.5 \quad 100$

$6.7 \quad 22$

$15.5 \quad 51$

0.62

$4.6 \quad 15$

$4.0 \quad 13$

2.17

$7.6 \quad 25$

1.55

$7.6 \quad 25$

$14.6 \quad 48$

$12.8 \quad 42$

$18.3 \quad 60$

$24.4 \quad 80$

1.55

9.130

$39.6 \quad 130$

1.55 
Limestone, gray, finely granular . . . . . . . . .

Phyllite, gray . . . . . . . . . . . . .

Graywacke, gray, fine-grained . . . . . . . .

Limestone, yellow-white . . . . . . . . . . .

Phyllite, gray . . . . . . . . . . . . .

Phaneritic igneous rock of intermediate composition. Sill?

Phyllite, gray . . . . . . . . . . . . .

Phaneritic igneous rock as above. Sill? . . . . . . .

Phyllite, gray to black; contains bed of brown hornfels .

Limestone, black, dense . . . . . . . . . . . .

Phyllite, gray; some beds limy . . . . . . . . . .

Limestone, gray-buff, finely crystalline . . . . . . .

Phyllite, gray . . . . . . . . . . . .

Limestone, buff, finely crystalline . . . . . . .
Phyllite, gray to black, limy, contains bed of brown

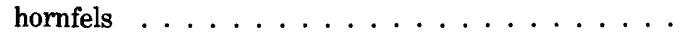

$2,528-2,530$

Limestone, gray

End of samples.

Total sampled thickness, upper part of Las Animas Formation

Total depth, 2,570

Igneous rocks in the Las Animas Formation include volcanic flow rocks, tuffs, and minor intrusive rocks, probably in sills. Andesite and basalt are present in the formation at the Haskins well, as are thin units of dioritic and granodioritic rocks. Edwards (1966) noted latite, andesite, and olivine basalt in other wells. He also reported (1966, p. 254) quartz latite porphyry at depth $4,010 \mathrm{ft}$ in the Lange Government well, but I saw no evidence of porphyry at that level or elsewhere in the well. However, the sample gap at 5,150-5,320 $\mathrm{ft}$ in the well (see type well) corresponds with marked lows in gammaray and neutron logs of the well, and these lows are inferred to reflect a mafic igneous rock. Edwards (1966) also reported dacitic tuff in well 3 and rhyolitic and latitic tuffs in well 1, figure 1. Tuffs also may have been a source of the silica in the chert and siliceous pelites at the Lange Government well, although such a lineage is not proved. Similarly, the schists in thin beds within units of phyllite or graywacke at the Haskins well quite likely were derived from tuffs or tuffaceous mudstones.

\section{SIGNIFICANCE OF LITHOLOGIES}

The differences between the sections at the Lange Government and the Haskins wells indicate substantial differences in the environments of deposition. The dark-gray to black, fine-grained siliceous and cherty sediments at the Lange Government site suggest deep-water deposi- 
tion, presumably marine. Although pelitic rocks and graywacke predominate at the Haskins site, carbonate and volcanic rocks are also present there. The carbonate rocks are in the form of single beds of crystalline limestone or dolomite and are principally in the lower part of the explored section. They suggest a shallower environment than do the chert-bearing rocks at the Lange Government well. The volcanic rocks at the Haskins site are in the form of thin flows that occur only in the dark-red or maroon upper part of the explored section. Both the volcanics and the red sedimentary rocks conceivably could have been deposited either subaerially or beneath water. Unless the red color was acquired after burial, however, the fine-grained red sediments suggest some combination of shallow-water marine and terrestrial deposition, perhaps similar to that of the Triassic Moenkopi Formation (Stewart and others, 1972). In brief, then, the Las Animas Formation seems to consist of deep-water deposits at the Lange Government well and of shallow-water deposits that grade upward into subaerial deposits $60 \mathrm{~km}$ to the east at the Haskins well.

In the absence of structural data, the stratigraphic relation between the two sections is unknown. If the two sections are in any part isochronous, then a deep-water facies was deposited in the west at the same time that a shallow-water to subaerial facies was deposited in the east. More likely, the two sections represent different parts of the Las Animas Formation. The section at the Lange Government well probably reflects an early stage of sedimentation, and the rocks in the explored section at the Haskins well represent a later stage, when the depositional trough or basin was nearly filled with sediments.

The biotitic rocks and hornfels in the lower part of the Lange Government well are interpreted as metamorphic effects of a deep-lying Tertiary intrusive body rather than as effects of burial alone. Mafic dikes of Tertiary age at the surface in the vicinity of the well (Johnson, 1969) may be an indication of such a body at depth. The dikes trend east in the area east of the Spanish Peaks intrusive center, parallel to major structure in the Precambrian basement (fig. 2). They are older and more mafic than the radial dikes of Spanish Peaks (Smith, 1978), and they evidently were derived from a different and deeper parent magma body than the radial dikes.

\section{THICKNESS}

The thickness of the Las Animas Formation is indeterminate in the absence of structural information and of boreholes to the base. The intercepts in the Lange Government and Haskins wells provide only apparent thicknesses that might differ appreciably from true thicknesses, depending on structure. If, as believed, the Haskins well 
is in a different and higher segment of the formation than the one at the Lange Government well, an unknown thickness may lie between the two segments. An unknown thickness also lies between the bottom of the Lange Government well and the base of the formation, and a further unknown thickness stratigraphically higher than the section at the Haskins well could exist. Thus the thickness of the Las Animas Formation may be great, and it probably much exceeds the 1,700-m (5,575-ft) combined thickness of the Lange Government and Haskins sections.

\section{AGE AND CORRELATION}

Although direct measures of the age of the Las Animas Formation are not available, the age is established within broad limits. The map pattern of Precambrian rocks in subsurface southeast Colorado (fig. 2) strongly suggests that the Las Animas Formation lies on granite. $\mathrm{An} \mathrm{Rb-Sr}$ age of 1,280 m.y. was obtained on the granite in one bordering locality many years ago (Muehlberger and others, 1966, fig. 1). On the basis of lithology and that age, all the bordering granite is assigned to a group of Precambrian granites of intermediate age in Colorado referred to as the $\backsim 1,400-$ m.y. age group (Tweto, 1977). Additional indication of a granite floor beneath the Las Animas Formation comes from the Lange No. 1 Marquez well (fig. 2, no. 9). The lithic record of this well is extremely poor, but the borehole apparently intersected some rocks of the Las Animas Formation and then entered granite of the $\sim 1,400-\mathrm{m}$.y. age group as identified in a granite core. As no evidence is known that the granite bordering and underlying the Las Animas Formation is intrusive into the formation, the Las Animas is concluded to be the younger, and thus to be less than 1,400 m.y. in age.

The Las Animas Formation is overlain in most places by Permian rocks generally referred to the upper parts of the Sangre de Cristo or Fountain Formations. In pre-Permian fault blocks in the eastern part of the area, however, Pennsylvanian, Ordovician, or Cambrian rocks overlie the Las Animas. The Cambrian rocks are Late Cambrian in age and generally are assigned to the Reagan Sandstone, but they have been variously assigned also to the Sawatch Quartzite, Peerless Formation, Lamotte Sandstone, Bonneterre Formation, or lower part of the Arbuckle Group. The Las Animas Formation therefore is older than Late Cambrian. On the basis of its metamorphic character and position unconformably below Upper Cambrian rocks, the Las Animas Formation is classed as late Precambrian (Proterozoic Y) in age.

The Las Animas Formation closely resembles the Tillman Metasedimentary Group of Ham, Denison, and Merritt (1964) in the 
Wichita Mountains province of southern Oklahoma (fig. 3), and it probably is of the same age as the Tillman. Like the Las Animas, the Tillman consists of moderately metamorphosed graywacke, pelitic rocks, and chert. Like the Las Animas also, it is younger than a granitic basement about 1,400 m.y. in age, and it is older than rhyolitic volcanic rocks about 525 m.y. (Middle Cambrian) in age. Ham, Denison, and Merritt (1964) regarded the Tillman as the basal fill in a deep structural trough at the site of the Wichita Mountains and inferred its age as Early Cambrian or late Precambrian. Recent deep seismic reflection profiling suggests that the Tillman is more widespread than originally was thought, its basin extending into the area south of the Wichita Mountains (Brewer and others, 1981). Likewise, the age is greater than originally was thought, although still not definitely established. On the basis of indirect evidence, R. E. Denison (oral commun., July 16, 1981) now places the Tillman in an age bracket between 1,200 and $1,400 \mathrm{~m} . \mathrm{y}$.

Whatever the precise age of the Las Animas and the Tillman, the similarities in character and occurrence suggest that the two formations were deposited in response to the same tectonic event. Both units are interpreted to have been deposited in deep troughs of rift origin trending about west-northwest through a widespread terrane of mesozonal granites about $1,400 \mathrm{~m} . \mathrm{y}$. in age. Owing to subsequent

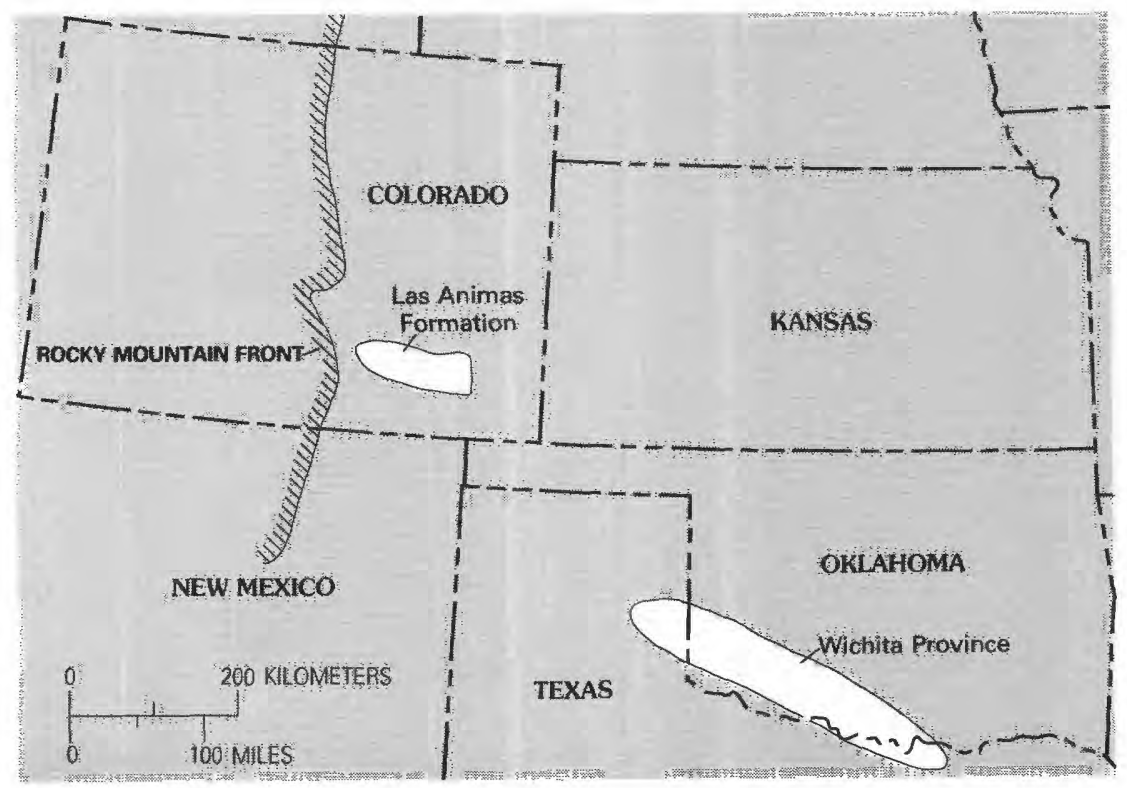

FIGURE 3.-Map showing relation of Las Animas Formation to Wichita province. 
deformation, particularly in the Pennsylvanian, the Precambrian sediments in the bottoms of the troughs now lie in deformed belts characterized by major faults with complex histories of movements (Ham and others, 1964; Tweto, 1980). Although problems of the tectonic relations and histories of the two belts are not treated here, it may be noted that the two belts are not connected or alined (fig. 3), despite assertions to the contrary (Moss, 1936, p. 948; Eardley, 1962, p. 39; King, 1969, p. 64).

\section{REFERENCES CITED}

Bayley, R. W., and Muehlberger, W. R., 1968, Basement rock map of the United States: U.S. Geological Survey.

Brewer, J. A., Brown, L. D., Steiner, D., Oliver, J. E., Kaufman, S., and Denison, R. E., 1981, Proterozoic basin in the southern Midcontinent of the United States revealed by COCORP deep seismic reflection profiling: Geology, v. 9, no. 12, p. $569-575$.

Eardley, A. J., 1962, Structural geology of North America (2d ed.): New York, Harper and Rowe, $743 \mathrm{p}$.

Edwards, Jonathan, Jr., 1966, The petrology and structure of the buried Precambrian basement of Colorado: Colorado School of Mines Quarterly, v. 61, no. 4, 436 p.

Ham, W. E., Denison, R. E., and Merritt, C. A., 1964, Basement rocks and structural evolution of southern Oklahoma: Oklahoma Geological Survey Bulletin $95,302 \mathrm{p}$.

Heaton, R. L., 1933, Ancestral Rockies and Mesozoic and late Paleozoic stratigraphy of Rocky Mountain region: American Association of Petroleum Geologists Bulletin, v. 17 , no. 2, p. 109-168.

Iohnson, R. B., 1969, Geologic map of the Trinidad quadrangle, south-central Colorado: U.S. Geological Survey Miscellaneous Investigations Map I-558.

King, P. B., 1969, The tectonics of North America-A discussion to accompany the tectonic map of North America, scale 1:5,000,000: U.S. Geological Survey Professional Paper 628, $95 \mathrm{p}$.

Maher, J. C., and Collins, J. B., 1949, Pre-Pennsylvanian geology of southwestern Kansas, southeastern Colorado, and the Oklahoma Panhandle: U.S. Geological Survey Oil and Gas Investigations Map 101.

Moss, R. G., 1936, Buried Precambrian surface in the United States: Geological Society of America Bulletin, v. 47, no. 6, p. 935-966.

Muehlberger, W. R., Hedge, C. E., Denison, R. E., and Marvin, R. F., 1966, Geochronology of the midcontinent region, United States, Part 3, Southern area: Journal of Geophysical Research, v. 71, no. 22, p. 5409-5426.

Smith, R. P., 1978, Geologic maps of part of the Spanish Peaks dike system, south-central Colorado: Geological Society of America Map and Chart Series MC-22.

Stewart, J. H., Poole, F. G., and Wilson, R. F., 1972, Stratigraphy and origin of the Triassic Moenkopi Formation and related strata in the Colorado Plateau region, with a section on Sedimentary petrology, by R. A. Cadigan: U.S. Geological Survey Professional Paper 691, 195 p.

Tweto, Ogden, 1977, Nomenclature of Precambrian rocks in Colorado: U.S. Geological Survey Bulletin 1422-D, 22 p.

-1980, Precambrian geology of Colorado, in Kent, H. C., and Porter, K. W., eds., Colorado geology: Denver, Colo., Rocky Mountain Association of Geologists, p. 37-46. 

. 

迹 